\title{
CORRESPONDENCE
}

\section{THE NEED FOR A PHILOSOPHY OF DEMOCRACY}

\author{
To THE EDITOR of Philosophy
}

Sir,

Among the few direct services which philosophers as such can render at the present time to the war effort of the United Nations is the clarification, elaboration and propagation of the theory of democracy. There would, I think, be general agreement that this theory is neither so well developed nor so well understood as it should be; and while there has been much thinking on the subject since the war began there are many points outstanding which call for further discussion. We still stand in need, in fact, of a comprehensive and coherent statement of the principles of democracy, and the need is, I submit, a most urgent one; for as you yourself pointed out, Sir, in your editorial of October I939, this war is a war of philosophies if ever any war was. We must know our resources, commitments and aims in the ideological as well as in the purely military sphere if we are eventually to triumph over our opponents; more particularly if we hope to consolidate our gains when the fighting is over and overcome not merely the substance but also the spirit of Fascism. Because I believe that philosophers have a clear and quite special responsibility in this matter, I am venturing to offer in a very brief form remarks on some of the leading principles of what I take to be a satisfactory philosophy of democracy. I do this more in the hope of stimulating others to put their views forward than for the intrinsic value of what follows.

I. The first point on which $I$ think stress should be laid is the simple one that democracy is rightly described as a philosophy. To many of us the word suggests primarily a special kind of political system, one in which the control of public policy is vested more or less directly in the whole body of the adult members of the State. This is of course the original meaning of the word, and the political aspect of democracy remains of great importance. Yet it would surely be absurd to believe it to exhaust the full content of modern democracy and to hold that now, for instance, our one aim is to preserve our peculiar form of government, or even the general type of which it is an instance. The truth is rather that the principle that government ought to be conducted in accordance with the wishes of the governed is only one of a whole series of principles cherished by democrats, and these principles jointly constitute what can properly be called the philosophy of democracy. Democracy is a political system, most certainly, and a defensible one at that; but it is much more too. It is also the belief in a given set of ethical principles or, more simply, in a set of rules of conduct which we think men should observe in their dealings with one another. It is, in short, a philosophy of living. If anyone doubts that, let him examine the behaviour and beliefs of our opponents. Fascism at any rate is not just another political system.

II. Having established that the word "democracy" thus has both a political and what is perhaps best called an ethical signification, we need next to consider the two separately. Of political democracy I shall have little to say here, except to suggest that, despite the private convictions of many, an adequate justification of it as an efficient form of government could be worked out if we recognized clearly the special characteristics it possesses in the modern world. We need first and foremost to see that in a large-scale community democracy can be effective only if different sections of the population play different parts (according to their several capacities) in the working of the political machine: to demand the same contribution and postulate the same intelligence in all is to stultify the democratic case from the start and to lay yourself open to all the criticisms which Socrates applied to the democracy of the Greeks. We can distinguish at least three main classes in 


\section{P H I L OSO P H Y}

a modern democratic State: the general body of the electorate, the more politicallyconscious members of the community and those who have expert knowledge of particular matters connected with government: and from each of these democracy requires its special service. What those services are, and what faculties they presuppose in those who are to perform them, I cannot here indicate; but I hope I have said enough to show that our attitude to many practical questions (e.g. the sphere of democratic education) will vary according to our view of the matter. And I do not see any answer to the Socratic criticism of political democracy except on these lines.

III. Important as the defence of political democracy is, however, it would seem still more vital at the present time to elaborate the philosophy of democracy proper. Here the first requisite is clearly to state the nature of the paramount democratic principle. That it is a principle of individuality we should probably all be prepared to agree: it is a truism almost too obvious to be stated that democrats aim above everything at the welfare of each and every imdividual member of the community. But if we come to look into them, are the meaning and implications of this principle so very evident? Can we produce, for instance, a plain ruling on the extent to which a democracy may justifiably compel its citizens to certain actions, even against their wishes? There might well be a measure of agreement over certain concrete cases; but a general principle remains to be formulated. For this philosophers must bear their share of responsibility. Their failure hitherto would seem to rest on a too ready acquiescence in the conception of the individual formulated by Locke and his school. It would of course be idle to deny the very great services rendered by Locke to the cause of liberty; nor can the historical connection of his followers with the growth of democracy all over the world be discounted. Yet it is quite consistent with this to insist that the Lockian view of politics is an entirely inadequate basis for a theory of modern democracy, if only because the social conditions on which it was built are now largely matters of history.

In this connection I think myself that it is important to pay particular attention to the place occupied by freedom in the democratic scheme of things. In much of our thinking we appear to equate the cause of democracy with the cause of liberty: to believe freedom of the very essence of democragy. Now while I should not wish to be thought to advocate in any way the restricting of democratic liberties, I do suggest that we ought to subject the general point to scrutiny. Surely, when we come to think about it, freedom is (or should be) valued by democrats not as an end in itself but as a means: democratic liberties exist to promote the good of individual members of democratic societies. If we took that view of freedom, I think, we might be a little more reluctant to extend its benefits to those who, like the supporters of modern Fascism, only wish to abuse it with a view to the ultimate destruction of democracy itself. If we do not take it, how are we to answer those critics of democracy who, like Plato, assert that democracy is pure libertarianism, the negation of an orderly society rather than a form of life to appeal to all? Democracy, after all, is not the same as anarchy; yet democrats often speak as if they subscribed to anarchistic principles without reserve.

IV. The vagueness among supporters of democracy about the precise significance of the principle of individuality is well illustrated when we pass to the next main heading of the democratic theory: the means by which a liberal society can be brought into existence. Over the general character of many of these there is a fair measure of agreement: President Roosevelt has himself named the "four freedoms" which he takes to be bulwarks of a decent society, and we should all be prepared to subscribe to others such as the provision of impartial justice, with real equality for all persons and all classes before the law. But the unsatisfactory nature of the theory of democracy betrays itself when we try to specify these means. Among the four freedoms the President named freedom from want; and all democrats would agree that in the world of the future this must be achieved if we are to approximate to a true democracy.. Does this mean, however, that the State will be justified in suppressing all economic initiative in the individual and in instituting a communist economy? Of course it would be absurd to expect philosophers to produce an easy and satisfactory answer to so difficult a puzzle; but it would be equally wrong to suppose that they have nothing to offer here. For, when we come to think about it, 


\title{
NEW B O O K S
}

the question of the economic relations of democracy is after all only part of the larger problem of the way in which individual initiative and public action are to be blended in the society of the future; and surely philosophers should have something to say on that head. It would seem obvious that neither the laisser-faire of the Victorians nor the system of full State control in all spheres envisaged by those who look for their model to Russia is really compatible with the attainment of democratic ends; democracy must take from both, but the borrowing must be made on principle. It is the task of philosophers to work out that principle; yet so far they seem to have progressed little beyond Bosanquet, whose formula limiting State action to the "hindering of hindrances" to the good life is plainly inadequate.

There are other matters in the philosophy of democracy, in particular the question of the autonomy of democratic values (as opposed to the Gleichschaltung of the Fascists) and of the connection of democracy with reason on the one hand and faith on the other, on which I should like to have written; but I hope I have said enough to make my main point: that we have a real service to perform here, and an urgent one.

\author{
I am, Sir, \\ Yours faithfully, \\ W. H. Warsh.
}

